\title{
TOTAL ERITROSIT DAN LEUKOSIT BROILER BETINA SETELAH PEMBERIAN JINTAN HITAM (Nigella sativa) SEBAGAI IMUNOMODULATOR DALAM AIR MINUM
}

\author{
Total Erythrocytes and Leukocytes of Female Broilers after Being Given by Black Cumnin (Nigella \\ sativa) as Immunomodulator in Their Drinking water
}

\author{
Noven Hariyani, Siswanto, Sri Suharyati, dan Purnama Edy Santosa \\ Department of Animal Husbandry Faculty of Agriculture Lampung University \\ Jl. Soemantri Brojonegoro No.1 Gedung Meneng Bandar Lampung 35145 \\ Telp (0721) 701583, Fax (0721)770347. \\ e-mail: novenhariyani@gmail.com
}

\begin{abstract}
The study aimed to determine the effects of black cumin extract (Nigella sativa) and determine the optimal dose of black cumin extract (Nigella sativa) on total erythrocytes and leukocytes broilers. This research was conducted from December 2019 to January 2020 at the Integrated Field Laboratory Unit of the Faculty of Agriculture, University of Lampung. The research data were analyzed at Pramitra Biolab Indonesia Laboratory, Bandar Lampung. The research material was 60 female broilers (strain Cobb CP 707). This study used a Completely Randomized Design with 4 treatments and 3 replications. The treatments in this study were drinking water without Nigella sativa (P0), drinking water with Nigella sativa $36 \mathrm{mg} / \mathrm{kg}$ BW/day (P1), drinking water with Nigella sativa $72 \mathrm{mg} / \mathrm{kg}$ BW/day (P2) and drinking water with Nigella sativa $144 \mathrm{mg} / \mathrm{kg} \mathrm{BW}$ /day (P3). Data obtained from observations were arranged in the form of simple tabulations and displayed in the form of histograms for descriptive analysis. Research showed that female broilers given black cumin (Nigella sativa) in their drinking water affected on the total erythrocytes which was in the normal range and the total leukocytes which were above the normal range in all treatment. The best dose of black cumin (Nigella sativa) in drinking water for each parameters was $144 \mathrm{mg} / \mathrm{kg} \mathrm{BW} /$ day for total erythrocytes and $72 \mathrm{mg} / \mathrm{kg} \mathrm{BW} /$ day for total leukocytes.
\end{abstract}

Keywords: Black cumin (Nigella sativa), Erythrocytes, Female broilers, Immunomodulator, Leukocytes

\begin{abstract}
ABSTRAK
Penelitian ini bertujuan untuk mengetahui pengaruh ekstrak jintan hitam (Nigella sativa) yang diberikan dalam air minum dan mengetahui dosis pemberian ekstrak jintan hitam (Nigella sativa) yang optimal terhadap total eritrosit dan leukosit broiler betina. Penelitian ini dilaksanakan Desember 2019 sampai Januari 2020 di unit kandang Laboratorium Lapang Terpadu Fakultas Pertanian, Universitas Lampung. Pemeriksaan total eritrosit dan leukosit dilakukan di Laboratorium Klinik Pramitra Biolab Indonesia, Bandar Lampung. Materi penelitian adalah 60 ekor broiler betina galur Cobb CP 707. Penelitian ini menggunakan Rancangan Acak Lengkap dengan 4 perlakuan dan 3 ulangan. Perlakuan pada penelitian ini yaitu air minum diberikan secara ad libitum terdiri dari air minum tanpa Nigella sativa (P0), air minum dengan Nigella sativa $36 \mathrm{mg} / \mathrm{kg} \mathrm{BB} /$ hari (P1), air minum dengan Nigella sativa $72 \mathrm{mg} / \mathrm{kg}$ BB/hari (P2) dan air minum dengan Nigella sativa $144 \mathrm{mg} / \mathrm{kg}$ BB/hari (P3). Data yang diperoleh dari hasil pengamatan disusun dalam bentuk tabulasi sederhana dan ditampilkan dalam bentuk histogram untuk dianalisis secara deskriptif. Penelitian menunjukkan bahwa pemberian jintan hitam (Nigella sativa) pada air minum mempengaruhi total eritrosit pada kisaran normal dan total leukosit diatas kisaran normal pada semua perlakuan. Dosis terbaik pemberian jintan hitam (Nigella sativa) pada broiler betina adalah 144 $\mathrm{mg} / \mathrm{kg} \mathrm{BB} /$ hari untuk total eritrosit dan $72 \mathrm{mg} / \mathrm{kg} \mathrm{BB} /$ hari untuk total leukosit.
\end{abstract}

Kata Kunci : Broiler Betina, Eritrosit, Jintan Hitam (Nigella sativa), Imunomodulator, Leukosit 


\section{PENDAHULUAN}

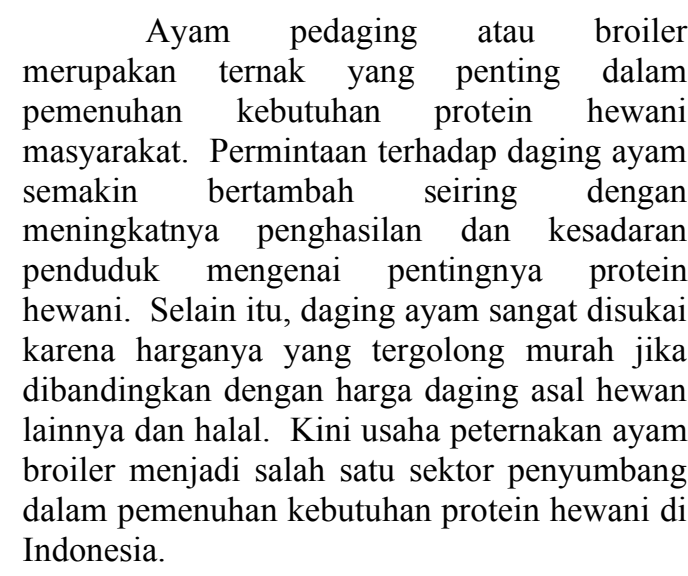

Kendala dalam sektor peternakan broiler yang dilihat dalam segi kesehatannya yaitu tingginya serangan penyakit pada broiler. Kesehatan merupakan faktor yang sangat menentukan keberhasilan usaha peternakan ayam broiler. Metode yang dapat digunakan untuk menilai status kesehatan broiler salah satunya melalui penilaian hematologi. Penilaian hematologi diantaranya dapat dilihat dari total sel darah merah (eritrosit) dan sel darah putih (leukosit) ayam broiler tersebut. Eritrosit merupakan salah satu sel darah penting bagi tubuh yang berfungsi mengikat $\mathrm{O}_{2}$ oleh hemoglobin ke dalam sel tubuh dan mengeluarkan karbondioksida dari sel tubuh (Suprijatna et al., 2005). Leukosit merupakan sel darah yang dapat membentuk sistem imun yang berperan dalam melawan berbagai penyakit infeksi dan benda asing (Isroli et al., 2009). Leukosit berfungsi melindungi tubuh terhadap berbagai penyakit dengan cara fagosit dan menghasilkan antibodi (Junguera, 1977).

Peternak dan perusahaan peternakan unggas biasanya menanggulangi permasalahan tersebut dengan cara melakukan pemberian antibiotik yang berguna untuk memberantas penyakit. Penggunaan antibiotik secara berlebihan dan dalam jangka waktu lama akan menimbulkan gangguan keseimbangan atau ketidakstabilan mikroorganisme dalam saluran pencernaan serta resistensi mikroorganisme terhadap antibiotik (An den bogaard dan Stobberingh, 2000), sehingga perlu alternatif pengganti antibiotik yaitu dengan penambahan imunomodulator.

Imunomodulator dapat didefinisikan sebagai suatu substansi, (biologis dan sintetis) yang dapat menstimulasi, menekan atau mengatur salah satu dari komponen sistem kekebalan, baik respon kekebalan spesifik maupun non spesifik. Penambahan imunomodulator diharapkan dapat meningkatkan sistem imun ayam yang ditandai dengan pertambahan sel darah putih dan sel darah merah pada tubuh ternak itu sendiri. Isroli et al. (2009) menyatakan bahwa untuk mengetahui tingkat kekebalan tubuh dapat dilihat dari variabel darah secara lengkap. Salah satu tanaman yang dapat digunakan sebagai imunomodulator adalah jintan hitam.

Jintan hitam (Nigella sativa) yang juga dikenal dengan "black cumin" adalah tanaman herbal tahunan yang termasuk dalam keluarga Ranunculaceae dan memiliki efek sebagai imunomodulator. Tanaman ini berasal dari daerah laut mediterania (Adamu, 2010). Jintan hitam memiliki kandungan berupa thymoquinone yang berfungsi sebagai antioksidan, antiinfeksi, antitumor dan antiinflamasi (Regheb et al., 2009). Berbagai penelitian pada manusia mengenai efek imunomodulator dari $N$. sativa telah dilakukan dan terbukti bahwa $N$. sativa dapat meningkatkan respon imun. Namun, pada saat ini khususnya pada broiler betina belum ada yang melakukan penelitian.

Penggunaan broiler betina dalam penelitian ini dilakukan karena broiler betina secara fisiologis merupakan ayam yang memiliki perbedaan dengan broiler jantan dilihat dari ukuran organ limfositnya. Limfosit sendiri merupakan bagian yang penting dalam sel darah terutama pada luekosit yang fungsi utamanya yaitu sebagai sistem kekebalan tubuh. Menurut Sturkie (2000) sel-sel limfoid broiler betina pertumbuhannya lebih lambat dan ukurannya lebih kecil dibandingkan dengan broiler jantan sehingga proses pembentukan antibodi broiler betina juga lebih lambat dan rendah. Ternak yang memiliki bobot limfoid yang besar, cenderung tahan terhadap berbagai penyakit. Pemberian ekstrak Nigella sativa yang dilarutkan ke dalam air minum diharapkan dapat menjaga keseimbangan sistem imun dan dapat meningkatkan total eritrosit dan leukosit broiler betina.

Sampai saat ini belum ada peneliti yang menyebutkan pengaruh pemberian Jintan hitam (Nigella sativa) terhadap total eritrosit dan leukosit broiler betina. Oleh karena itu, penulis tertarik melakukan penelitian mengenai pengaruh pemberian Jintan hitam (Nigella sativa) guna meningkatkan kesehatan broiler yang dapat diamati dari total eritrosit dan leukosit broiler. 


\section{MATERI DAN METODE}

\section{Waktu dan Tempat}

Penelitian ini dilaksanakan pada Desember 2019-Januari 2020 di unit kandang Laboratorium Lapang Terpadu yang berada di Fakultas Pertanian, Universitas Lampung. Analisis total eritrosit dan leukosit dilaksanakan di Laboratorium Klinik Pramitra Biolab Indonesia, Bandar Lampung.

\section{Materi}

Peralatan yang digunakan pada kandang penelitian antara lain kandang broiler, sekat besi, sekat bambu, waring, sekam dan koran, plastik terpal, lampu, spuit untuk vaksinasi, tempat ransum (babychick feeder), tempat air minum, nampan air dipping, ember, hand sprayer, timbangan manual, timbangan elektrik, thermohygrometer, karung dan plastik serta peralatan yang digunakan untuk pengambilan darah antara lain kapas alkohol, disposable syringe, tabung ethylene diamine tetraacetic acid (EDTA), box untuk sampel darah, gunting dan pisau, peralatan pemeriksaan total eritrosit dan leukosit (Hematologi Analyzer Rayto RT-76005), es batu, alat tulis dan kertas.

Bahan-bahan yang digunakan dalam penelitian ini antara lain doc broiler betina strain Cobb CP $707^{\mathrm{R}}$ sebanyak 60 ekor (tidak vaksin), ransum broiler komersial, vaksin yang meliputi vaksin ND, AI, dan IBD/gumboro, bahan untuk biosecurity seperti desinfektan dan kapur, sediaan Nigella sativa dalam bentuk ekstrak kering (kapsul), bahan yang digunakan untuk analisis total eritrosit dan leukosit antara lain diluent, rinse, lyse, probe cleanser, alkohol, darah broiler dan air minum.

\section{Metode Penelitian}

Metode yang digunakan pada penelitian ini yaitu metode eksperimental menggunakan Rancangan Acak Lengkap (RAL) dengan perletakan petak percobaan secara acak, terdiri atas 4 perlakuan dan 3 ulangan yaitu P0 : air minum tanpa Nigella sativa (jintan hitam), P1 : air minum dengan dosis $36 \mathrm{mg} / \mathrm{kg} \mathrm{BB} /$ hari Nigella sativa (jintan hitam), P2 : air minum dengan dosis $72 \mathrm{mg} / \mathrm{kg}$ BB/hari Nigella sativa (jintan hitam), P3 : air minum dengan dosis $144 \mathrm{mg} / \mathrm{kg} \mathrm{BB} / \mathrm{hari}$ Nigella sativa (jintan hitam). Setiap ulangan terdiri dari 5 ekor broiler.

\section{Pelaksanaan Penelitian}

Pelaksanaan penelitian antara lain kegiatan persiapan kandang dilakukan minimal satu minggu sebelum DOC datang (chick in), melakukan pemeliharaan selama 30 hari dengan memisahkan broiler ke dalam petakpetak kandang sejak umur 1 hari dan setiap petak kandang terdiri dari 5 ekor ayam, melakukan program vaksinasi agar ayam tidak terserang penyakit. Vaksin yang diberikan terdiri dari vaksin Newcastle Disease (ND) dan Avian Influenzan (AI) (killed vaccine), ND (live vaccine) dan Gumboro. Vaksin ND kombinasi AI (killed vaccine) diberikan saat ayam berumur 6 hari melalui injeksi subkutan leher bersamaan dengan vaksin ND (live) diberikan melalui tetes mata. Vaksin Gumboro dilakukan pada saat ayam berumur 12 hari melalui air minum.

Pengambilan sampel darah dilakukan pada hari ke-31 di pagi hari. Sampel darah diambil sebanyak 1 ekor dari setiap petak percobaan (12 sampel). Sampel darah diambil menggunakan disposable syringe $5 \mathrm{ml}$ melalui vena brachialis sebanyak 2--3 ml kemudian dimasukan ke dalam tabung (Ethylene Diamine Tetra Acetic) EDTA dan diberi label sesuai dengan perlakuan. Meletakkan tabung sampel darah ke dalam colling box, selanjutnya sampel darah dalam tabung EDTA dikirim ke Laboratorium Klinik Pramitra dalam rantai dingin untuk dihitung total eritrosit dan leukositnya.

\section{Analisis data \\ Data yang diperoleh dari hasil pengamatan dibuat dalam bentuk tabulasi sederhana dan histogram kemudian dianalisis secara deskriptif.}

\section{HASIL DAN PEMBAHASAN}

\section{A. Pengaruh Perlakuan terhadap Total Eritrosit pada Broiler Betina}

Hasil penelitian pengaruh perlakuan pemberian Nigella sativa (jintan hitam) terhadap total eritrosit broiler betina menunjukkan rata-rata jumlah eritrosit pada masing-masing perlakuan adalah P0 $(2,3 \times$ $\left.10^{6} / \mathrm{mm}^{3}\right)$, P1 $\left(2,4 \times 10^{6} / \mathrm{mm}^{3}\right)$, P2 $(2,4 \times$ $\left.10^{6} / \mathrm{mm}^{3}\right)$, P3 $\left(2,5 \times 10^{6} / \mathrm{mm}^{3}\right)$. Hasil penelitian dari semua perlakuan menunjukkan bahwa rata-rata total eritrosit broiler betina masih berada dalam kisaran normal. Dharmawan (2002) menyatakan bahwa total eritrosit normal pada ayam broiler berkisar antara 2,3--3,5 $\times$ $10^{6} / \mathrm{mm}^{3}$. Data jumlah eritrosit broiler betina dapat dilihat pada Tabel 1. 
Tabel 1. Rata-rata jumlah eritrosit broiler betina

\begin{tabular}{|c|c|c|c|c|}
\hline \multirow{2}{*}{ Ulangan } & \multicolumn{4}{|c|}{ Perlakuan } \\
\hline & $\mathrm{P} 0$ & P1 & $\mathrm{P} 2$ & P3 \\
\hline & \multicolumn{4}{|c|}{ 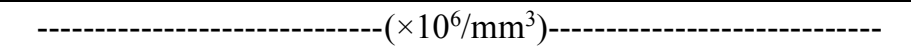 } \\
\hline 1 & 2,17 & 2,35 & 2,27 & 2,54 \\
\hline 2 & 2,41 & 2,43 & 2,49 & 2,38 \\
\hline 3 & 2,37 & 2,41 & 2,57 & 2,48 \\
\hline Jumlah & 6,95 & 7,19 & 7,33 & 7,4 \\
\hline Rata-rata & 2,3 & 2,4 & 2,4 & 2,5 \\
\hline
\end{tabular}

Keterangan:

P0: Air minum tanpa Nigella sativa (jintan hitam);

P1: Air minum dengan $36 \mathrm{mg} / \mathrm{kg} \mathrm{BB} /$ hari Nigella sativa (jintan hitam);

P2: Air minum dengan $72 \mathrm{mg} / \mathrm{kg} \mathrm{BB} /$ hari Nigella sativa (jintan hitam);

P3: Air minum dengan $144 \mathrm{mg} / \mathrm{kg} \mathrm{BB} /$ hari Nigella sativa (jintan hitam).

Berdasarkan histogram yang disajikan pada Gambar 1, rata-rata jumlah eritrosit meningkat seiring meningkatnya dosis yang diberikan. Kelompok Nigella sativa dengan dosis yang lebih tinggi memiliki rata-rata eritrosit paling tinggi yaitu pada pemberian jintan hitam dengan dosis $144 \mathrm{mg} / \mathrm{kg} \mathrm{BB} /$ hari (P3), hal tersebut kemungkinan terjadi diduga karena pada P3 dosis pemberian Nigella sativa dua kali lipat lebih tinggi daripada dosis pemberian pada perlakuan lain sehingga salah satu kandungan aktif Nigella sativa berupa thymoquinone otomatis akan lebih banyak pada P3 dimana thymoquinone sendiri merupakan senyawa yang dapat mencegah terjadinya penurunan eritrosit. Hal ini sesuai dengan pendapat Naz (2011) yang menyatakan bahwa thymoquinone (TQ) dapat menjaga hematologi darah misalnya mencegah terjadi penurunan eritrosit, leukosit, eusinofil dan heterofil.

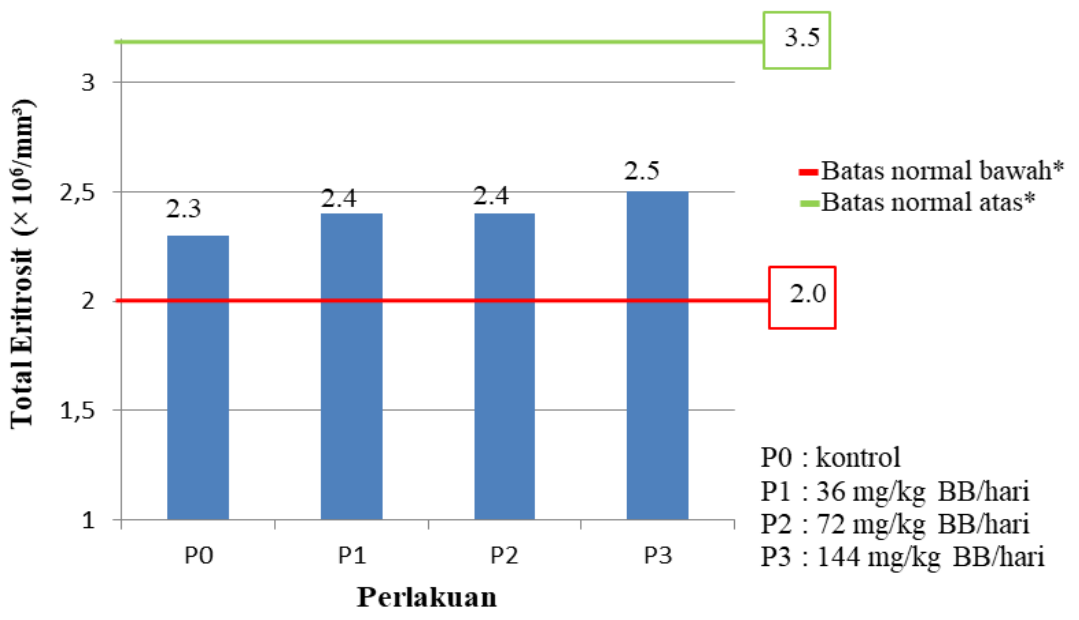

Gambar 1. Rata-rata jumlah eritrosit

Keterangan:

* : Rataan total eritrosit menurut Dharmawan (2002).

Kandungan senyawa thymoquinone yang lebih tinggi pada P3 diduga mampu meningkatkan dan memicu pembentukan hemoglobin yang merupakan bagian dalam eritrosit. Al-Homidan et al. (2002) menyatakan bahwa dengan pemberian jintan hitam yang mengandung thymoquinone dapat menyebabkan peningkatan secara signifikan terhadap jumlah hemoglobin. Menurut Sturkie (1998) di dalam eritrosit terdapat hemoglobin $(\mathrm{Hb})$ sehingga apabila hemoglobin meningkat karena kandungan aktif Nigella sativa berupa thymoquinone maka otomatis eritrosit meningkat karena hemoglobin merupakan 
salah satu bagian dari eritrosit. Seperti diketahui bahwa pada penelitian sebelumsebelumnya dengan menggunakan materi penelitian bukan broiler, penggunaan jintan hitam sudah terbukti mampu meningkatkan eritrosit karena kandungan senyawa seperti thymoquinone dan minyak atsiri. Kandungankandungan senyawa tersebut juga diduga mampu meningkatkan enzim-enzim pencernaan serta sebagai zat antimikrobial pada broiler sehingga apabila enzim-enzim pencernaan meningkat seperti enzim proteolitik maka efisiensi asam amino didalam usus pun meningkat, hal tersebut mampu meningkatkan sistem imun dengan penurunan populasi mikroba patogen di dalam saluran pencernaan. Senyawa-senyawa tersebut dapat berfungsi dengan baik sehingga mampu menstimulasi sistem imunitas yang dapat meningkatkan jumlah eritrosit. Menurut Nasir (2009) kandungan serbuk jintan hitam berupa zat aktif (thymoquinone, dithymoquinone, thymol, dan carvacrol) dapat meningkatkan kecernaan dan absorbsi zat makanan dengan cara menstimulasi enzim-enzim pencernaan. Menurut Kusdarwati et al. (2010) senyawa fenol dari minyak atsiri berperan dalam membunuh bakteri, yaitu dengan cara mendenaturasi protein sel bakteri. Terdenaturasinya protein sel bakteri akan menyebabkan semua aktivitas metabolisme sel bakteri terhenti, sebab semua aktivitas metabolisme sel bakteri dikatalisis oleh enzim yang merupakan protein.

Aktivitas biologis dari jintan hitam telah banyak dilaporkan sebagai antioksidan yang baik. Komposisi senyawa jintan hitam berupa protein, karbohidrat dan lemak diduga mampu mencegah kerusakan sel dengan cara menangkal radikal bebas di dalam tubuh sehingga total eritrosit broiler betina dalam penelitian ini dapat bertahan lebih lama dan tetap berada pada kisaran normal. Menurut Kurnia et al. (2011) komposisi nutrisi jintan hitam yaitu protein $21 \%$, karbohidrat $35 \%$ dan lemak $35--38 \%$ dikenal sebagai senyawa yang mampu untuuk menangkal radikal bebas di dalam tubuh.

Komposisi nutrisi pada jintan hitam seperti protein, karbohidrat dan lemak akan membantu penangkapan radikal bebas yang masuk ke dalam tubuh broiler dimana senyawa-senyawa tersebut akan berikatan dengan radikal bebas yang dibantu oleh hemoglobin $(\mathrm{Hb})$ sehingga pembentukan radikal bebas dalam darah akan terhambat dan pembentukan eritrosit akan mengalami peningkatan. Sarma et al. (2010) menyatakan bahwa antiradikal bebas (antioksidan) merupakan aktivitas suatu senyawa yang dalam kadar rendah dapat mencegah terjadinya oksidasi dari substrat yang mudah teroksidasi serta cara kerja dari senyawa antioksidan adalah bereaksi dengan radikal bebas reaktif membentuk radikal bebas tak reaktif yang relatif stabil. Antioksidan menstabilkan radikal bebas dengan melengkapi kekurangan elektron yang dimiliki radikal bebas, dan menghambat terjadinya reaksi berantai dari pembentukan radikal bebas.

Penyebab lain yang dimungkinkan meningkatkan total eritrosit broiler betina pada penelitian ini diduga karena kandungan vitamin yang ada pada jintan hitam seperti vitamin riboflavin (B2), piridoksin (B6) dan vitamin C yang mampu meningkatkan pembentukan atau produksi eritrosit (erythropoiesis). Menurut Yulianti (2006) menyatakan bahwa jintan hitam juga mempunyai kandungan berupa vitamin A, B1, B2, B6, C, E dan niacin. Menurut Siswanto (2017) pembentukan eritrosit membutuhkan vitamin B12, B6, B2, nicotinic acid, pantothenic acid, biotin, dan vitamin $\mathrm{C}$.

Kandungan nutrisi lainnya dari jintan hitam yang diduga dapat mempercepat proses erythropoiesis (produksi dan pematangan eritrosit) yaitu asam amino dan asam lemak essensial. Meyer dan Harvey (2004) menyatakan bahwa yang harus ada untuk erythropoiesis normal adalah asam amino, asam lemak essensial, mineral, dan vitamin. Menurut Niluh (2012) jintan hitam juga mengandung asam lemak, terutama asam lemak esensial tak jenuh (linoleic acid dan linolenic acid) dimana asam lemak esensial terdiri dari alfa-linolenic acid (Omega-3) dan linoleic acid (Omega-6) sebagai pembentuk sel. Yulianti (2006) menambahkan bahwa jintan hitam juga mempunyai kandungan saponin, nigellin, asam amino dan bermacammacam mineral.

Peningkatan pada perlakuan ketiga (P3) juga diduga karena dosis yang diberikan telah sesuai sehingga jintan hitam berperan sebagai imunostimulan yang dapat meningkatkan sistem kekebalan broiler betina melalui peningkatan total eritrosit yang dihasilkan. Menurut Sasmito (2017) sistem kekebalan (imunomodulator) pada broiler dibagi menjadi tiga, yaitu sebagai imunostimulan (meningkatkan sistem kekebalan), imunorestorasi (memperbaiki sistem kekebalan), dan imunosupresan (menekan sistem kekebalan). 
Banyak faktor lainnya juga yang dapat mempengaruhi jumlah eritrosit. Swenson (1984) menyatakan bahwa faktor -faktor yang dapat memengaruhi jumlah eritrosit dalam darah yaitu umur, produksi telur, peningkatan epinephrine, volume darah, pemeliharaan, waktu, temperatur lingkungan, dan faktor iklim.

\section{B. Pengaruh Perlakuan terhadap Total Leukosit pada Broiler Betina}

Hasil penelitian pengaruh perlakuan pemberian Nigella sativa (jintan hitam) terhadap total leukosit broiler betina menunjukkan rata-rata jumlah leukosit pada masing-masing perlakuan adalah P0 (108,15 × $\left.10^{3} / \mathrm{mm}^{3}\right)$, P1 $\left(120,65 \times 10^{3} / \mathrm{mm}^{3}\right)$, P2 $(123,28$ $\left.\times 10^{3} / \mathrm{mm}^{3}\right)$, P3 $\left(117,35 \times 10^{3} / \mathrm{mm}^{3}\right)$. Nilai rata-rata dari kadar leukosit broiler betina masing-masing perlakuan pada Tabel 2 menunjukkan bahwa kadar leukosit antar perlakuan berada diatas kisaran normal dan tergolong mengalami peningkatan yang sangat tinggi dari kadar normalnya yaitu berkisar

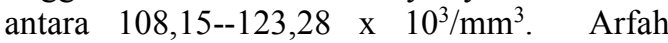
(2015) melaporkan bahwa jumlah leukosit normal pada ayam berada pada kisaran 12--30 $\times \quad 10^{3} / \mathrm{mm}^{3}$. Julendra et al. (2010) mengemukakan bahwa jumlah sel leukosit normal pada ayam adalah antara 12.000-30.000/ $\mu 1$.

Kemungkinan yang menyebabkan total leukositnya berada diatas kisaran normal diduga karena keadaan suhu kandang diatas suhu normal dimana ayam mengalami cekaman panas sehingga menyebabkan total leukositnya tinggi. Keadaan rata-rata suhu kandang dalam penelitian ini sebesar $29,8^{\circ} \mathrm{C}$ dan kelembaban $77 \%$. Menurut Kartasudjana dan Suprijatna (2010) ayam broiler dapat tumbuh secara optimal pada suhu lingkungan $18--24^{\circ} \mathrm{C}$, dengan kelembaban 50--75\%. Lohmann (2004) menambahkan bahwa suhu nyaman ayam umur $15--24$ hari yaitu $2--28^{\circ} \mathrm{C}$. Hodges (1977) menyatakan bahwa jumlah leukosit pada tiap-tiap unggas berbeda-beda dan mempunyai fluktuasi yang tinggi, keadaan ini bisa terjadi pada kondisi stress, aktivitas biologis yang tinggi, gizi, dan umur. Faktor lain yang turut berpengaruh adalah jenis kelamin, lingkungan, efek hormon, obat-obatan serta sinar ultraviolet atau sinar radiasi. Data jumlah leukosit broiler betina dapat dilihat pada Tabel 2 .

Tabel 2. Rata-rata jumlah leukosit broiler betina

\begin{tabular}{ccccc}
\hline \multirow{2}{*}{ Ulangan } & \multicolumn{3}{c}{ Perlakuan } \\
\cline { 2 - 4 } & & P0 & P1 & P2 \\
\hline 1 & 94,86 & 119,69 & 128,82 & 124,38 \\
2 & 117,35 & 121,51 & 119,48 & 107,74 \\
3 & 112,25 & 120,76 & 121,55 & 119,86 \\
\hline Jumlah & 324,46 & 361,96 & 369,85 & 351,98 \\
\hline Rata-rata & 108,15 & 120,65 & 123,28 & 117,35
\end{tabular}

Keterangan:

P0: Air minum tanpa Nigella sativa (jintan hitam);

P1: Air minum dengan $36 \mathrm{mg} / \mathrm{kg} \mathrm{BB} /$ hari Nigella sativa (jintan hitam);

P2: Air minum dengan $72 \mathrm{mg} / \mathrm{kg} \mathrm{BB} /$ hari Nigella sativa (jintan hitam);

P3: Air minum dengan $144 \mathrm{mg} / \mathrm{kg} \mathrm{BB} /$ hari Nigella sativa (jintan hitam).

Berdasarkan histogram pada Gambar 2 terlihat bahwa adanya peningkatan total leukosit paling tinggi pada perlakuan kedua (P2) dibanding dengan kontrol (P0), Peningkatan jumlah leukosit diduga karena kandungan yang terdapat didalam nigella sativa (jintan hitam) seperti ekstrak metanolnya banyak berperan dalam sistem kekebalan (imunomodulator) dengan cara meningkatkan aktivitas fagositosis makrofag dari broiler betina dimana leukosit sendiri merupakan sel darah yang melindungi tubuh terhadap kumankuman penyakit yang menyerang tubuh dengan cara fagosit dan menghasilkan antibodi. Ghonime et al. (2011) melakukan penelitian terhadap tiga tanaman herbal (Silene nocturna, Nigella sativa, dan Matricaria chamomilla) yang tumbuh di Mesir terhadap tikus Balb/C, menunjukkan adanya peningkatan sel leukosit, sel sumsum tulang dan peningkatan bobot limfa pada dosis yang digunakan. Hasil penelitian yang dilakukan terhadap tikus 
Balb/C menunjukkan bahwa ketiga tanaman obat tersebut termasuk jintan hitam memiliki efek imunomodulator. Ekstrak metanol jintan hitam yang diberikan secara intraperitoneal, dapat meningkatkan jumlah sel darah putih (hingga $1,2 \times 10^{4} \mathrm{sel} / \mathrm{mm}^{3}$ ).

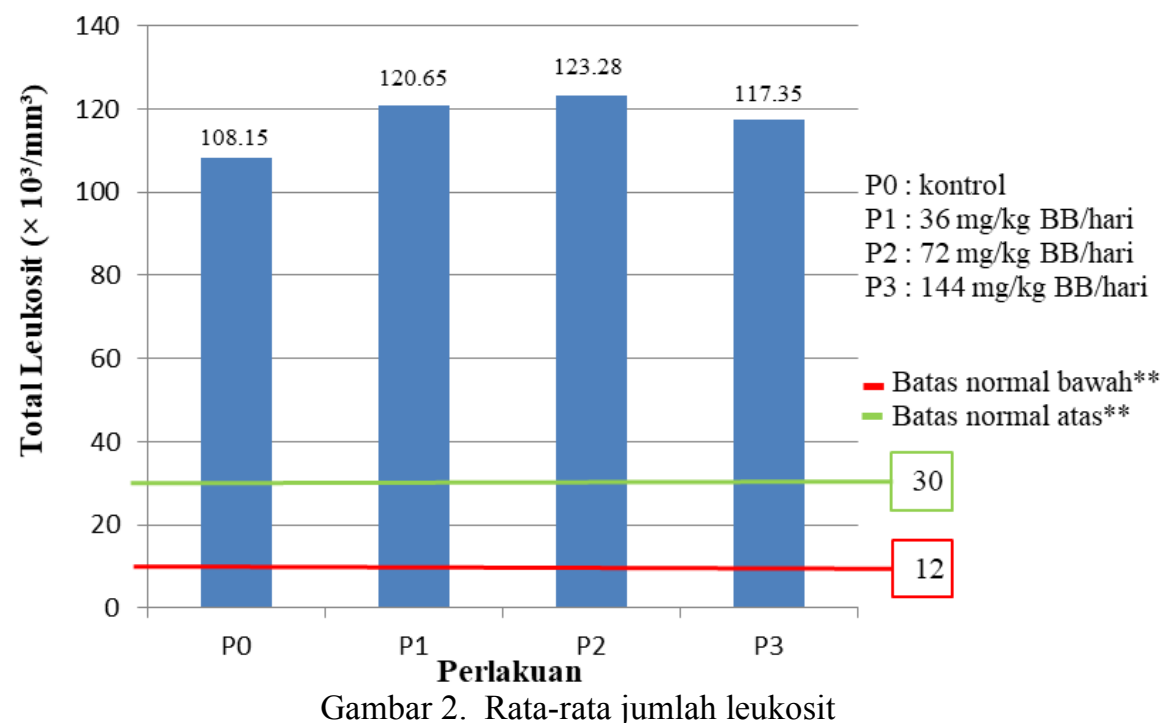

Keterangan:

**: Rataan total leukosit menurut Arfah (2015).

Peningkatan leukosit dalam sirkulasi menggambarkan ketanggapan sel darah putih dalam mencegah hadirnya agen penyakit dan peradangan yang ditandai dengan pertumbuhan organ limfosit. Organ limfosit broiler betina terbilang pertumbuhannya lambat dan ukurannya kecil daripada organ limfosit broiler jantan sehingga perlu ditingkatkan pertumbuhannya dengan pemberian jintan hitam dimana jintan hitam sendiri diduga mampu meningkatkan proliferasi organ limfosit broiler betina. Hal ini sesuai pernyataan Sturkie (2000) yang menyatakan bahwa sel-sel limfoid broiler betina pertumbuhannya lebih lambat dan ukurannya lebih kecil dibandingkan dengan broiler jantan sehingga proses pembentukan antibodi broiler betina juga lebih lambat dan rendah. Ternak yang memiliki bobot limfoid yang besar, cenderung tahan terhadap berbagai penyakit. Menurut Khasanah (2009) jintan hitam dapat meningkatkan proliferasi limfosit mencit Balb/C pada dosis 0,52 dan 5,2 mg/hari. Meningkatnya proliferasi sel limfosit ini, terutama sel B, dapat meningkatkan diferensiasi sel dan berkembang menjadi sel plasma yang membentuk antibodi.

Penyebab lain yang dimungkinkan menyebabkan total leukosit pada penelitian ini tinggi diduga karena bahan aktif yang terdapat dalam jintan hitam berupa thymoquinone bekerja sebagai imunostimulan yang meningkatkan produksi antibodi tubuh broiler ditunjukkan dengan adanya peningkatan leukosit. Menurut Suhatri dan Aldi (2010) penggunaan ekstrak jintan hitam sangat efektif untuk meningkatkan sistem imun atau sebagai imunostimulan. Peningkatan jumlah total leukosit menunjukkan kemampuan sistem imun untuk melawan infeksi atau benda asing. Leukosit yang merupakan sistem imun alamiah (spesifik) berperan penting dalam melindungi tubuh dari serangan mikroorganisme. El Kadi dan Kandil (1987) dalam Sari (2009) menyatakan bahwa mekanisme kerja dari jintan hitam sebagai imunostimulan adalah melalui sistem imunitas non spesifik, yaitu dengan meningkatkan aktivitas dan jumlah sel darah putih (leukosit) serta melalui sistem imunitas spesifik terutama pada sistem imun spesifik seluler dengan cara meningkatkan rasio antara sel T helper (Th) dengan sel T suppressor (Ts). Menurut Vieira (2011) menyatakan bahwa jumlah total leukosit yang berada pada batas tertinggi normal menunjukkan sistem imun memproduksi jumlah total leukosit yang cukup dalam sirkulasi darah untuk melawan infeksi.

Data hasil histogram (Gambar 2) pada perlakuan ketiga (P3) menunjukkan total leukosit mengalami penurunan. Menurunnya jumlah leukosit diduga karena kandungan saponin P3 lebih tinggi dua kali lipat 
dibandingkan dari dosis yang lainnya sehingga pada P3 kadar saponin yang masuk ke dalam tubuh broiler lebih banyak. Selain mengandung bahan aktif berupa thymoquinone dan yang lainnya menurut Dontriska et al. (2014) jintan hitam juga mengandung senyawa yang menekan pembentukan leukosit yaitu senyawa saponin, sehingga menyebabkan jintan hitam berubah fungsi dari imunostimulan menjadi imunosupresan atau racun yang menekan pembentukan leukosit. Menurut Mulyana (2002) saponin adalah jenis glikosida dan merupakan racun yang dapat menghancurkan butir darah atau hemolisis.

\section{SIMPULAN DAN SARAN}

\section{Simpulan}

Berdasarkan penelitian yang telah dilakukan dapat disimpulkan bahwa pemberian Nigella sativa (jintan hitam) pada broiler betina mempengaruhi total eritrosit pada kisaran normal dan total leukosit diatas kisaran normal pada semua perlakuan. Dosis terbaik pemberian Nigella sativa (jintan hitam) adalah $144 \mathrm{mg} / \mathrm{kg}$ BB/hari dan $72 \mathrm{mg} / \mathrm{kg} \mathrm{BB} /$ hari untuk total leukosit broiler betina.

\section{Saran}

Berdasarkan penelitian ini, penulis menyarankan untuk dapat melakukan penelitian lanjut guna mengetahui total eritrosit dan leukosit pada broiler betina setiap minggu untuk mengetahui tingkat penggunaan Nigella sativa (jintan hitam) yang lebih optimal.

\section{DAFTAR PUSTAKA}

Adamu, H. M. 2010. Identification of Essential Oil Components from Nigella sativa Seed by Gas Chromatography Mass Spectroscopy. J. Pakistan of Nutrition 9 (10): 966--967

Al-Homidan, A., A. A. AL-Qarawi, S. A. Al Waily, and S. E. I. Adam. 2002. Response of broiler chicks to dietary Rhazyastricta and Nigella sativa. Poult. Sci. 43(2): 291--296

An den Bogaard, A. E. and E. E. Stobberingh 2000. Epidemiology of resistance to antibiotics. J. Int. Ant. Agents 24: 327--335

Arfah, N. H. 2015. Pengaruh pemberian tepung kunyit pada ransum terhadap jumlah eritrosit, hemoglobin, pcv, dan leukosit ayam broiler. Skripsi.
Universitas Hasannudin Makasar. Makasar

Dharmawan, N. S. 2002. Pengantar Patologi Klinik Veteriner. Hematologi Klinik. Universitas Udayana. Denpasar

Dontriska., A. D. Sasanti., dan Yulisman. 2014. Efektivitas tepung jintan hitam (Nigella sativa) untuk mencegah infeksi Aeromonas hydrophila pada Ikan Patin. J. Ind. Of Akuakultur Rawa 2(2):188--201

El-Kadi, A., and O.I. Kandil. 1987. The black seed (Nigella sativa) and immunity: its effect on human $\mathrm{T}$ cell subset. Fed. Proc. 46(4): 1222

Ghonime M., R. Eldomany., A. Abdelaziz., and H. Soliman. 2011. Evaluation of Immunomodulatory Effect of Three Herbal Plants Growing in Egypt. $J$. Immunopharmacol Immunotoxicol 33(1):141--145

Hodges, R.D. 1977. Normal Avian Haematology. Comparative Clinical Haematolgy. Blackwell Scientific: Oxford

Isroli., S., Susansi., E. Widiastuti., T. Yudiarti., dan Sugiharto. 2009. Observasi Beberapa Variabel Hematologis Ayam Kedu pada Pemeliharaan Intensif. Prosiding Seminar Nasional Kebangkitan Peternakan. Universitas Diponegoro

Julendra H., Zuprizal, dan Supadmo. 2010. Penggunaan Tepung Cacing Tanah (Lumbricus rubellus) sebagai Aditif Pakan terhadap Penampilan Produksi Ayam Pedaging, Profil Darah, dan Kecernaan Protein. Buletin Peternakan 34(1):21--29

Junguera, L. C. 1977. Basic Histology. Edisi 8. McGraw-Hill. New York

Kartasudjana, R dan E. Suprijatna. 2010. Manajemen Ternak Unggas. Penebar Swadaya. Jakarta

Khasanah, N. 2009. Pengaruh Pemberian Ekstrak Nigella sativa terhadap Respon Proliferasi Limfosit Limfa Mencit Balb/C yang diinfeksi S. Typhimurium. Fakultas Kedokteran, Universitas Diponegoro, Semarang

Kurnia, H., N. Permatasari., dan Subandi. 2011. Pengaruh Ekstrak Jintan Hitam Terhadap MDA dan Sel Spermatogonium Tikus yang Dipapar Asap Rokok Kretek Subakut. Jurnal Kedokteran Brawijaya 26(3):161-165 
Kusdarwati, R., S. Ludira., dan T. M. Akhmad. 2010. Daya antibakteri ekstrak buah adas (Foeniculum vulgare) terhadap bakteri Micrococcus luteus secara in vitro. J. Ilmiah Perikanan dan Kelautan 2(1):32--41

Lohmann. 2004. Manual Guide Logman Layer. Japfa Comfeed Indonesia Tbk. Jakarta

Meyer D.J dan J. W. Harvey. 2004. Veterinery Laboratory Medicine Interpretation and Diagnosis. $3^{\text {rd }}$ Edition. Saunders: USA

Mulyana, 2002. Ekstraksi senyawa aktif alkaloid, kuinon, dan saponin dari tumbuhan kecubung sebagai larvasida dan insektisida terhadap nyamuk Aedes aeygepti. Skripsi. Institut Pertanian Bogor

Nasir, Z. 2009. Comparison of effects of Echinacea purpure a juices and Nigella sativa seeds on performance, some blood parameters, carcass and meat quality of broilers. Dissertation Agricultural of Sciences. University of Hohenheim.

Naz, H. 2011. Nigella sativa: themiracul os herb. J. Pakistan of Biochem. Mol. Bio 44(1):44--48

Niluh, R.W. 2012. Pemberian salep ekstrak jinten hitam (Nigella sativa) terhadap peningkatan kepadatan sabut kolagen pada mukosa oral marmot (Cavia cobaya). J. Oral biology dental 4(1):30--34

Regheb, A., A. Attia, W. S. Eldin, F. Elbarbry, S. Gazarin and A. Shoker. 2009. The protective effect of tymoquinone, anti oxidant and anti inflammatoryagent, againt renal injury: J. Saudi Kidney Dis Transpl. Review 20(5):741--752

Rosmalawati, N. 2008. Pengaruh Penggunaan Tepung Daun Sembung (Blumen Balamifera dalam Ransum terhadap Profil Darah Ayam Broiler Periode Finisher. Skripsi. IPB: Bogor

Sarma, A. D., A. R. Mallick., and A. K. Ghosh. 2010. Free Radicals and Their Rolein Different Clinical Conditions:An Overview. J. Int. of Pharma Sciences and Research 1(3):185--192

Sari, A.I.P. 2009. Pengaruh Pemberian ekstrak Nigella sativa terhadap Produksi NO Makrofag Mencit $\mathrm{Balb} / \mathrm{C}$ yang diinduksi Salmonella typhimurium. Fakultas Kedokteran, Universitas Diponegoro. Semarang

Sasmito, E. 2017. Imunomodulator Bahan Alami. Rapha Publishing. Yogyakarta

Siswanto, 2017. Darah dan Cairan Tubuh. Diktat Fisiologi Veteriner 1. Universitas Udayana. Denpasar

Sturkie, P. D. 1998. Avian Physiology. $5^{\text {th }}$ Edition. Spinger Verleg. New York 2000. Avian Physiology $3^{\text {th }} \mathrm{ed}$. Springer Verlag. New York

Suhatri dan Y. Aldi. 2010. Aktifitas Ekstrak Etanol Biji Jintan Hitam (Nigella Sativa Linn) Terhadap Titer Antibodi dan Jumlah Sel Leukosit pada Mencit Putih Jantan. Fakultas Farmasi Universitas Andalas.

Sultana, S., H. M. Asif., N. Akhtar., A. Iqbal., H. Nazar., dan R. E. Rehman. 2015. "Nigella sativa: Monograph". Journal of Pharmacognosy and Phytochemistry 4(4):103--106

Suprijatna, E., U. Atmomarsono., dan R. Kartasudjana. 2005. Ilmu Dasar Ternak Unggas. Penebar Swadaya. Jakarta

Swenson, M. J. 1984. Duke's Physiology of Domestic Animals. 10 Edition. Publishing Associattes a Divisin of Cornell University. Ithaca and London 1993. Physiological Properties and Celluler and Chemical Constituent of Blood in Dukes Physiology of Domestic Animals, 11 Edition. Comstock Publishing Associates a Division of Cornell University Press Ithaca and London. New York

Vieira, K. 2011. Improving Abnormal Results. University Of Florida College Of Medicine

Yulianti, S. 2006. Sembuhkan Penyakit dengan Habbatussauda. Agromedia Pustaka: Jakarta

Zeweil, H. S., M. H. Ahmed., M. M. El-Adawy., and B. Zaki. 2008. Evaluation of Substituting Nigella Seed Meal as Source of protein for Soybean Meal in Diets of New Zealand White Rabbits. $9^{\text {th }}$ World Rabbit Congress. Nutrition and Digestive Physiology 863-867. 